\title{
A Primer For Accounting Certification: Complete Analysis Of The Process With Listing Of Sources
}

David T. Boyd, Kazakhstan Institute of Management, Kazakhstan Sanithia C. Boyd, Kazakhstan Institute of Management, Kazakhstan Priscilla Berry, Jacksonville University, USA

\begin{abstract}
As a result of globalization and the growth and complexity of both domestic and international bodies requiring accountants, the need for highly sophisticated training and specific certification is mandatory. Students seeking career positions in the field of accounting are amazingly left without the easy access to certification that one might think would be readily available. Interest in, and the quest for, certification is domestic and international and across all study fields. To be fully prepared a well-equipped accountant today will be cross functional and have "proof" of his/her knowledge in the form of certifications in other fields as well as being multi-national by holding certifications issued in countries where he/she practices or travels. Currently, because the field is being transformed so rapidly by world events and the economy, students, as well as practitioners, need more easily accessible information on what certifications are available and how to achieve them. This document identifies and reviews accounting requirements and major certifications in accounting, finance, and information technology, including the recently developed fields of fraud and forensic accounting. Basic access information is provided for each requirement and certification and web addresses for additional data relating to qualification and certification are included.
\end{abstract}

Keywords: accounting certifications; international; cross-discipline; students

\section{INTRODUCTION}

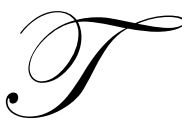

he scenario from yester year! He is sitting at the back of the office area. His wooden roll top desk is likely positioned in the corner of the room and is littered with paperwork. He is wearing a white shirt with a dark skinny tie. The sleeves on his shirt are pulled up on his arms and held in place by elastic bands around his biceps to prevent the sleeves of his shirt from interfering with his work. His bulky, workscarred briefcase sits at his feet on the floor patiently waiting for leftover work to be placed inside. It will be taken home for further labor tonight. His green eyeshades, \#2 wooden pencils, and small round spectacles are trademarks of his profession. Over many years, he earned a reputation as a math geek who was more comfortable writing little numbers in little boxes than he was interacting with people.

Flash forward. The accounting world of today is often characterized by virtual teams in virtual offices around the world meeting the needs of ethnically diverse and sophisticated clients. Also, the classroom and the Board Rooms are dominated by the female gender; and if the numbers in the Board Rooms do not suggest parity in the world of practicing accountants, the numbers will soon reflect what we see in the classroom today.. The he of yesteryear is likely to be a she today. The accountants of the $21^{\text {st }}$ century are a cross-section of male and female, and there are representatives from every nationality in the world. Many practicing accountants are bilingual, if not multi-lingual, and have the ability to comfortably travel the world in the performance of their skills and be at ease and in communicating with people of diverse cultures. The current accounting classrooms are in the process of radically changing the way accountants do business. The first wave of emerging multi-national, multi-discipline 
accountants has "hit the street" and they have a clear advantage in the profession.

Gone are the green eyeshades and endless hours of entering little numbers in little boxes on little pieces of paper. Data entry is performed by specially trained technicians, leaving the accountant free to perform more specialized functions. The data is accessed by wireless laptop computers from anywhere in the world. Paraphrasing an old tobacco commercial, today's accountant can say with confidence, "We've come a long way, baby."

Today's well-trained, highly educated accountants still perform the traditional audit function of systematically gathering evidence regarding management's economic assertions about a company and communicating the results to interested users. But the accountant of the $21^{\text {st }}$ century also performs many other critical functions. Management, investors, and lenders no longer function at any level without the skills and expertise of a certified accountant. Among the wide range of functions performed by an accountant are assurance

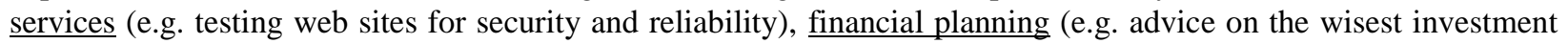
of money), technology (e.g. advising clients on the use of information technology and overseeing software applications, system design, and web site development), tax (e.g. advising clients on tax compliance and tax planning), and consulting (e.g. advising clients in how to improve their operation, acquisitions and mergers).

In short, today's accountant must be ready to perform not only his/her traditional accounting tasks but s/he must also stand ready to advise and make financial and technology related decisions. And if that isn't enough, the accountant is called upon to perform in an international setting.

Accountants once operated with tunnel vision and were very limited in the tasks performed, today's accountant has wide fields from which to choose, if s/he wishes. As with many other professions like legal and medical, accountants are now able to specialize and become certified in specific areas. Certification, no matter the area of expertise, requires a wide range of knowledge in order to pass the exam. In addition, most certifications require a certain level of achievement in education and work experience in the field of certification. Although certification is a rigorous process, there are specific benefits in certification for the individual, the clients, and the employers. Experience in the field and specialized certification strengthens the credibility of the certificate holder. In addition, certified accountants generally attract a substantially higher salary than non-certified accountants.

Accounting certifications are no longer, however, the final answer. The market place now requires multifunctioning and demonstration of expertise in other closely related disciplines. For the accountant who would be most marketable in this current business climate, this would include proficiencies in finance and in information technology at a minimum. The accountant offering advice in these areas should be able to demonstrate the necessary level of expertise. To substantiate this claim it is necessary to become certified in the cross-discipline field.

One final note should be of interest to the reader. As baby-boom accountants begin leaving the workforce or at least take a lesser role, the opportunities for new entrants into the profession increase. This shift, coupled with the late 1990's decrease of enrollment in accounting programs nationwide in response to the implementation of the 150 hour requirement, has left the profession with lower numbers of qualified candidates. More jobs and swift advancement could be the order of the day for the accountant who is prepared through certification and an education background to support specific disciplines and assignments requiring experience in diversity and international experience.

If there is one area in which accountants are uniformly uninformed, or misinformed, it would have to be certification. Questions about the requirements for education, work experience, residency, age, nationality, testing centers are not answered in one place or in one package. The lack of this information is not limited to the domestic United States. This research compilation will answer many of the questions and address common misunderstandings and provide access to sources for other information.

The paper identifies and briefly discusses certifications in the accounting, finance, and information technology fields. While no site or list could be consider definitive in the current context of world affairs or fluid economic environment, the list of certifications available in the areas indicated, including the international 
certificates are given with the expectation that it will assist in making career decisions concerning certification. Web addresses are provided for the interested reader to access for more specific information.

\section{AMERICAN ACCOUNTING CERTIFICATIONS}

\section{The Certified Public Accountant}

The CPA certification is recognized worldwide for its prestige because of the process and the strict educational and testing requirements. This certification is supported and administered by the American Institute of Certified Public Accountants (AICPA), which dates back to 1887 with the formation of the American Association of Public Accountants (AAPA). See also: Certified Public Accountant (CPA) (www.aicpa.org). Although CPAs have been known stero- typically for the preparation of taxes and performance of audits, they are educated and certified to provide the information for all business and personal financial decisions. For example, the new breed of CPAs can devise accounting information systems for businesses, prepare tax returns, conduct financial audits of operations, perform performance reviews of employee best practices, provide financial data, interpret results, draft contingence plans for operations management and other decision making tools. To become certified in public accountancy, requirement for education, examination, and experience are specific.

The education requirement is, and will continue to be, the subject of much discussion within the accounting profession. It consists, in most jurisdictions, of a baccalaureate degree or its equivalent at a minimum. By the year 2009, all but seven states, California, Colorado, Delaware, Minnesota, New Hampshire, Pennsylvania, and Vermont, will require 150 hours of educational credits in order to sit for the CPA exam. Several of these require a masters' degree while others only specify that the applicant have 150 semester credit hours on transcript. In theory, the additional college hours would appear to be of benefit to both the candidate and the accounting profession, but most states do not proscribe the additional transcript hours to the accounting or a field related to accounting, thus raising questions about the real benefit of the additional hours. This hour requirement should be self-selected and channeled by the student with the hours going to a specific expertise development. The experience requirement is as varied among the states as is the education requirement. It ranges from zero to six years or more depending on the state and the extent of the candidate's education. Because of the variation in education and experience requirements among the states, anyone interested in becoming certified as a CPA should first contact the state board of accountancy in the state in which they plan to sit TABLE I lists web addresses by state or jurisdiction (see appendix). The board will provide the candidate with an exam application, directions pertaining to the exam, the regulations, and the board's rules.

The format of the CPA exam has recently changed to a computer based test consisting of four sections:

1. Auditing and Attestation $/ 4 \frac{1}{2}$ hours

2. Financial Accounting and Reporting/ 4 hours

3. Regulation $/ 3$ hours

4. Business Environment and Concepts/ $2 \frac{1}{2} 2$ hours

Each section contains several "testlets" of approximately 25 multiple choice questions each. With the exception of Business Environment and Concepts, testlets are followed by one or more "simulation" questions which may require computer based research to answer.

CPAs must continue to select opportunities for professional growth and develop their knowledge of the changing accounting issues. Continuing professional education (CPE) is, therefore, required by most states after certification. State boards mandate as much as 40 hours of CPE each year. Again, because of the differences among states and jurisdictions, those interested should contact their state board for the details for that individual state. This is a question that the student must ask for the state.

With the prestige and integrity of the CPA designation, many employment opportunities exist for those achieving certification. Certified Public Accounting firms vary from small, local firms to the Big Four accounting firms and many international firms, all eager to hire a well prepared CPA to work for them. The CPA can be found 
in almost any area of the United States and around the world. Positions for CPAs are available in almost any imaginable employment situation. Government at all levels from municipal entities to the federal government offer many opportunities for the CPA interested in governmental accounting. Perhaps the largest numbers of CPAs are in private practice that is they have their own small firm or they are part of a larger firm, serving clients, large and small, around the globe.

\section{The Certified Management Accountant}

CMAs are individuals who have demonstrated expertise which is crucial to the managerial decision-making process. See also: Certified Management Accountant (CMA) (www.imanet.org). This certification provides evidence of the candidate's knowledge and skills which are necessary to be an effective and influential participant of management teams. Employers worldwide seek new CPA employees who are CMAs and encourage current employees to attain their certification. The CMA certification was first offered in 1972 and is supported by the Institute of Management Accountants (IMA). An affiliate of the IMA is the Institute of Certified Management Accountants (ICMA). The ICMA is responsible for preparing and grading the certification exam. The IMA consists of approximately 82,000 members and serves as the world's "largest management accounting association."

CMAs must meet a set of requirements to become certified. These include the following:

- $\quad$ Apply for admission to ICMA and register to take the CMA examination

- $\quad$ Belong to the Institute of Management Accountants

- $\quad$ Graduate with a baccalaureate degree or its equivalent

- $\quad$ Pass the four sections of the CMA examination within a period of three years

- Fulfill the professional experience requirement: complete two consecutive years in a management accounting position employing management accounting principles with line decision authority

- $\quad$ Adhere to the Standards of Ethical Conduct

$\bullet$

The CMA exam is computer-based. Three of the four parts of the exam are entirely multiple-choice. The fourth is entirely written responses and problems. The four parts of the exam are the following:

1. Business Analysis/ 3 hours, 110 multiple choice questions

2. Management Accounting and Reporting/ 4 hours, 140 multiple choice questions

3. Strategic Management/ 3 hours, 110 multiple choice questions and

4. Business Applications/ 3 hours, 3-7 written response essays and problems

A candidate should note that the Business Analysis may be waived under certain conditions. If the applicant is already certified, s/he should check the web site for a list of qualifying exemptions. In the United States, these sites include the CPA, CFA, and CIA certificates. Others include certain Chartered Accountants and CPAs received from Hong Kong, Japan, People's Republic of China, and Taiwan.

To remain certified as a CMA, three requirements must be met. The first is to continue to adhere to the Standards of Ethical Conduct. The second is a continuing education requirement of at least 30 annual hours after passing the exam. The third requirement is to continue to be a member of the IMA. All of these requirements must be met in order to remain certified as a CMA.

Because of the knowledge required of CMAs, job opportunities are open at all levels of business in all areas of the world. With businesses and markets expanding throughout the world, CMAs have unlimited opportunities to find the ultimate career position.

\section{Certified Internal Auditor}

Certification in internal auditing might be appropriate for a career as an auditor in a corporation or government entity. See also: Certified Internal Auditor (CIA) (www.iia.org). Internationally, this is the only certification for internal auditors. The responsibilities of a CIA include mastery in identifying risks, examining 
alternative solutions, and suggesting the most appropriate solution to control those risks. The Institute of Internal Auditors, Inc. (IIA) first established the CIA certification in 1974.

The five requirements to obtain and maintain a certification in internal auditing are the following:

1. Understand the IIS's Standards for the Professional Practice of Internal Auditing

2. Graduate with a diploma from a recognized institution of higher learning or equivalent

3. Score 75 percent or higher on all sections of the CIA exam

4. Receive two years of experience in the field of internal auditing or equivalent

5. Meet the continuing professional development requirements

The CIA exam, like the CPA exam, is a rigorous two day assessment and the test focuses on the internal audit process with concentration in the following four areas:

Part I: The Internal Audit Activity's Role in Governance, Risk, and Control

Part II: Conducting the Internal Audit Engagement

Part III: Business Analysis and Information Technology, and

Part IV: Business Management Skills

The IIA offers professional recognition credit for Part IV to applicants who hold other professional certifications. The credit is for a wide array of certificates from around the world. For a complete list of eligible certificates, interested parties should visit the IIA web page. following:

The IIA also offers specialty certification for current holders of the CIA certificate. These include the

- $\quad$ Certification in Control Self-Assessment (CCSA),

- $\quad$ Certified Government Auditing Professional (CGAP), and

- $\quad$ Certified Financial Services Auditor (CFSA).

To remain certified, 80 hours of Continuing Professional Development (CPD) must be completed and reported every two years by practicing CIAs. This requirement maintains skills and knowledge as well as topical currency in field.

As with other certifications, a Certified Internal Auditor is knowledgeable in all areas of business. For this reason, businesses worldwide have need for CIAs and provide them with an opportunity to work closely with top management to better serve the needs of all types of enterprises.

\section{Certified Fraud Examiner (CFE)}

For those who might seek a more exciting work assignment, a CFE certificate might be more appealing. See also: Certified Fraud Examine (CFE) (www.cfenet.com). CFEs specialize in detecting and preventing fraud in various areas of business. Responsibilities of a CFE include resolving cases involving fraud, gathering evidence, obtaining statements and filling out reports, giving court testimony to findings, and aiding authorities in the detection and prevention of fraud. A fraud auditor is trained not only in the detection of fraud, but also the situations which permit fraud to occur. A CFE examines the company's information system to determine ways it is compromised and analyzes the internal controls for transactions completed off-line. The Association of Certified Fraud Examiners (ACFE) is one of the newer organizations in the international accounting community, but it has made great strides in a short time.

The association currently has in excess of 36,000 members, domestic and international. The membership is comprised of various professionals including attorneys, educators, auditors, fraud investigators, accountants, and loss prevention specialists. In the early years of the $21^{\text {st }}$ century, Enron, WorldCom, Global Crossing, Adelphia, and other major companies suffered significant losses due to perpetrators of fraud. These events only served to highlight 
the need for development of expertise in the area of fraud prevention. The ACFE serves this new area of accounting.

Requirements for a CFE certification are the following:

1. Bachelor's degree (or equivalent) from a "recognized institution of higher learning." Part of the education requirement can be waived based on proof of experience in identified fields including:

a. Accounting and auditing

b. Criminology and sociology

c. Fraud investigation

d. Loss prevention, and Law

2. Professional experience of two years in a related field

3. Successful completion of the CFE examination

Candidates complete their exam on a computer diskette which is sent to National Headquarters for grading. The integrity of the exam is guarded closely through control of the content and timing of each exam. No two exams are alike. The exam covers the following:

1. Criminology and ethics/ 2.6 hours, 125 questions

2. Financial transactions/ 2.6 hours, 125 questions

3. Fraud investigation/ 2.6 hours, 125 questions

4. Legal elements of fraud/ 2.6 hours, 125 questions

The ACFE specifies that to maintain certification, CFEs must complete Continuing Professional Education (CPE) requirements of 20 hours per year, or an accumulation of 60 hours over a three year period. Fifty percent of the CPEs must be directly related to detecting and preventing fraud.

Job opportunities for CFEs cover a wide range of careers including tax service and general accounting, personal financial planning, litigation support, technology solutions, estate administration, estate planning, construction industry, medical practices, forensic/fraud accounting, and business valuation.

\section{Certified Forensic Accountant}

Multi-disciplinary in its scope, the ACFEI actively promotes the dissemination of forensic information. The association's purpose is the continued advancement of forensic examination and consultation across the many professional fields of their membership. See also: Certified Forensic Accountant (CrFA) (www.acfei.com) ACFEI has elevated standards through education and training. The forensic accountant is only one of the professions under the umbrella of the ACFEI.

Forensic accountants use a blend of education and experience to apply accounting, auditing, and investigative skills to uncover evidence of fact, form legal opinions, and assist in investigations. They may be involved in litigation support, providing assistance on a given case, primarily related to the calculation or estimation of economic damages and related issues, and in investigative accounting or looking into illegal activities.

Forensic accountants work with financial institutions, attorneys, courts, including bankruptcy, and companies seeking assistance in their internal control efforts as well as proactive fraud investigations. Forensic accountants have a world of professional opportunities open to them as a result of their unique specialized training and skills.

The CrFA program may be unique in that it requires participants to be a Certified Public Accountant. Beyond the CPA prerequisite, the only other requirement is that applicants pass the CrFA exam. There are several ways to prepare for the test including self-study using materials and texts recommended by the ACFEI, but perhaps the most common method is to attend a review course conducted by the organization at one of its regional or national meetings. The review covers the following: 
The basics of forensic accounting including, judicial procedures and the gathering of evidence

- The engagement covering litigation-consulting and testifying

- $\quad$ Fraud

- Valuation

- $\quad$ Additional services: analysis of damages, accountant liability, tax failure and consulting failure

The multiple choice exam is usually given the day following the review course at the same location. Because of its requirement of a pre-existing CPA designation, the CrFA could be considered a specialty area to be added to the CPA.

The CrFA requires continuing education (CE) each year. This can be accomplished in a number of ways including mini tests in the Forensic Examiner journal and attending seminars at the regional and national conferences.

\section{Across Discipline Certifications}

As was indicated above, the highly trained, well prepared accountant of the $21^{\text {st }}$ century should be crossdiscipline knowledgeable and certified. Upon graduation, most students have a minor in a discipline other than accounting and the second discipline is often in finance or information technology. Additional hours may often be required to pass the test for certification. These additional requirements should be at a minimum. Cross certification may often cost, however, many employers will pay for this additional education. The cross discipline certification will provide economic benefits in almost every case. Cross discipline certificates that would enhance the credentials of the well prepared accountant are the following:

Certified Information Systems Auditor (CISA) (www.isaca.org)

The Information Systems Audit and Control Association (ISACA) have sponsored the Certified Information Systems Auditor (CISA) program since 1978. CISA is the globally accepted standard of achievement among information systems audit control and security professionals. Possessing the CISA designation demonstrates proficiency and is the basis for measurement in the profession.

To achieve the CISA certification an applicant must:

- $\quad$ Complete the CISA exam

- $\quad$ Adhere to the ISACA Code of Professional Ethics

- Submit verified evidence of a minimum of five years of professional IS audit, control, assurance and security work experience. Under certain circumstances substitution and waivers of such experience may be obtained.

The CISA exam, consisting of 200 multiple-choice questions and is given twice a year in June and December in designated locations. Content areas are the following:

- Information Systems Audit Process

- Information Technology Governance

- $\quad$ Systems and Infrastructure Lifecycle Management

- Information Technology Service Delivery and Support

- $\quad$ Protection of Information Assets

- $\quad$ Business Continuity and Disaster Recovery

Study guides, review manuals, and review courses are available through ISACA and local ISACA chapters. 
Chartered Financial Analyst (CFA) (www.cfainstitute.org)

The CFA Institute comprises more than 83,000 individual members and 134 member societies around the globe. Individual members either hold the CFA designation or are active in the investment business.

The CFA is the credential of choice for finance and investment professionals. It is to them what the CPA or CA is to the global accountant. To become a candidate one must:

- $\quad$ Fulfill the entrance requirements of the following:

- Having a U.S. bachelor's (or equivalent) degree, be in the final year of your bachelor's degree program, or have four years of qualified, professional work experience or a combination of work and college experience that totals at least four years.

- Meeting the professional conduct admission criteria

$\circ$ Taking the examinations in English.

- $\quad$ Sign-up for the first exam.

The amount of study and materials to be studied is determined by the candidate body of knowledge (CBOK). The CFA Institute believes a candidate should devote a minimum of 250 hours of study to each of the three exams. The exam consists of three "levels." The Level I exam must be passed before proceeding to Level II; Level II must be passed before proceeding to Level III. The exam is given twice each year in June and December in designated locations around the world. The material covered on each of the three exams includes ethical and professional standards, quantitative methods, economics, financial statement analysis, corporate finance, analysis of: equity investments, fixed income investments, and derivatives, and asset valuation. Score results are not released. Only a pass/fail notification is sent to the candidate.

\section{Certified Financial Planner (CFP) ( $\underline{\text { www.cfp.net }})$}

A CFP is qualified to provide clients with general financial planning services. Many financial planners are also registered as investment advisers or hold insurance or securities licenses that permit them to buy or sell products. Some planners may refer you to more specialized financial advisers to help you implement a financial plan. Many accountants have broadened their activities in recent years into areas outside of the traditional auditing, compilation, tax, etc. and expanded their services into financial planning. With the right education and experience an accountant, can easily qualify for the CFP certificate. This would enable a person to take clients through the financial planning process with the credentials that make him/her credible.

The steps to becoming a Certified Financial Planner are the following:

1. Complete the education requirement /currently a Bachelors' degree

2. Pass the certification examination

3. $\quad$ Meet the experience requirement

4. Adhere to the Code of Ethics and Professional Responsibility; pass a background check

5. Pay certification dues

The CFP exam consists entirely of multiple-choice questions. Some are of a brief statement of fact or scenario followed by several multiple-questions. The remainder present an extensive case scenario followed by 10 20 multiple-choice questions covering the scenario presented. Exam locations are scattered across the U.S. The exam is offered in March, July, and November of each year and lasts for 10 hours over $1 \frac{1}{2}$ days. Courses of study to prepare for the exam include self-study using materials recommended by the CFP and many university sponsored programs in which you can study on-line or in live classroom sessions.

Certified Treasury Professional (CTP) (www.afponline.org)

The Certified Treasury Professional certificate is administered by the Association for Financial 
Professionals (AFP). Employers, faced with critical staffing decisions, are looking at certification as an added value in prospective employees. The CTP is one choice toward achieving that added value.

The CTP exam is computer based and is administered through a commercial testing center at locations across the U.S. There are two examination windows each year: December/January and June/July. Preparation for the exam is based on Essentials of Treasury Management, a publication of the AFP, which covers a wide array of finance, accounting, economics, and treasury management topics. The topics covered in the exam include:

- Role of Treasury Management

- Treasury Organizational Structure

- Financial Environment

- Financial Accounting

- Financial Planning and Analysis

- Philosophy of Working Capital

- Working Capital Tools

- Payment Systems

- Cash Positioning

- Liquidity Management

- Treasury Systems and Information Management
- Electronic Commerce

- Sources of Capital and Leasing

- Capital Structure and Dividend Policy

- Global Treasury Environment

- Global Treasury Organization and Liquidity Management

- Financial Risk Management

- Enterprise Risk Management

- Corporate Governance and Ethics

- Pension Fund Management

- Relationship Management

The CTP exam is entirely multiple-choice and contains 170 questions. Study and preparation may be with a live instructor-led, on-line instructor-led or self-directed format.

\section{Global Certifications}

The world is getting smaller! How many times have you heard that statement? Well, it is - in a virtual sense anyway. One additional tool the well-equipped accountant can place in his/her briefcase is an international certification. The selection for the international certification will depend on where s/he plans to practice. The American CPA is widely recognized and accepted around the world. But there are, inevitably, times when a certificate from the country in which the accountant is practicing adds value to the accountant's repertoire. TABLE II is a listing of some of the certifications available in countries outside the United States (see appendix). The list is not intended to be exhaustive, but provides a snapshot of the diversity of accounting certifications. The serious accountant intent on building an impressive set of credentials should check for available options in the country in which s/he intends to practice.

\section{Chartered Accountant (CA) (www.icaew.co.uk)}

With more than 127,000 members, the Institute of Chartered Accountants in England and Wales (ICAEW) is the largest accountancy body for chartered accountants and auditors in the United Kingdom. There is no legal requirement for an accountant to be a paid-up member of the ICAEW. To be admitted to membership applicants must normally complete a period of relevant work experience and pass a series of examinations. The work experience lasts for three to five years and must be with an employer approved by the Institute. If an individual describes themselves as a "chartered accountant" they must be a member of the ICAEW or a recognized overseas equivalent. If they are in practice, they must comply with additional regulations pertaining to insurance and inspections.

Requirements for achieving the Chartered Accountant certificate are vague but generally relate to experience with an approved employer and a two-stage testing process. Information from the ICAEW is silent concerning educational requirements. The Mutual Recognition Directive of the EU permits EEA and Swiss nationals holding a professional qualification in their country to become a member of the equivalent body in another member state if they pass an aptitude test covering local tax and company law. 
As shown in TABLE II, the CA is available in at least 23 countries around the world. Generally, those offering this certificate correspond to the former British Colonies. The requirements for membership or charter status have evolved differently in each country since they were granted independence. Interested practitioners should check the regulations for the country of interest.

\section{Certified General Accountant (CGA) (www.thinkcga.org)}

Certified General Accountants (CGA) is professional accountants and is members of the Certified General Accountants Association of Canada. The association was formed in 1908 and currently has over 41,000 certified members. The CGA program of professional studies is offered in Canada, Bermuda, several Caribbean countries, and in a number of universities in China and Hong Kong. CGAs work in public practice firms, government, industry, commerce, and the non-profit sector. CGAs are authorized to conduct audits in every province and territory in Canada except Quebec.

Certification as a CGA requires the following:

- $\quad$ Education - varies depending on the program the student enters

- $\quad$ Practical work experience - generally about 3 years

- $\quad$ Course requirements - varies but, at a minimum, must include the CGAs PACE level examinations

Association of Chartered Certified Accountants (ACCA) (www.acca-business.org)

The Association of Chartered Certified Accountants (ACCA) is a British professional accounting body with a global presence that offers the Chartered Certified Accountant (CCA) qualification worldwide. It is one of the largest professional organizations of accountants in the world. Following an extensive and detailed study, ACCA has announced a new professional qualification which is to begin in December 2007. The new scheme requires 14 professional exams. Up to nine of the exams can be waived depending on educational level and prior certifications of the applicant. Subjects examined include financial accounting, management accounting, auditing, taxation, company law, financial management, management information systems and strategic management.

\section{Additional Certifications}

When one examines the list of certifications currently available, it is seemingly infinite. New ones continue to appear on a regular basis. They cover every conceivable aspect of accounting, finance, information technology and other areas of study. It seems that someone, somewhere, is always seeking a new niche. With the expansion of the European Union and the awakening of the newly independent countries of the former Soviet Union, the list is sure to continue to grow as these countries seek to develop their own certified experts. Interested accounting practitioners should engage in a web search to find certifications available by area of expertise and geographic locale.

\section{SUMMARY}

The need for, and rise of, the multinational accountant should be no surprise in this age of globalism. Today's job market for accountants is moving rapidly toward internationalization. Developing companies in developing countries seek knowledgeable accountants who have proven their international expertise. A college degree may no longer be enough. Increasingly, employers also want individuals who have a valid and reliable means of representing their professional and practical expertise. Certification is one answer to the escalating expectations of proficiency.

The requirements for achieving certification are as varied as the certifications themselves. On the upper end of the scale, perhaps, is the highly regarded and highly sought American CPA. The minimum education, in most instances, is the equivalent of a master's degree. The rigorous two-day exam leaves many an aspiring accountant lying in its wake. Only a relatively small percentage of those who take the exam ever achieve certification. According to the Winter/Spring 2006 publication of "The Uniform CPA Examination Alert" published 
by the AICPA, the percentages of candidate who passed each section of the Uniform CPA Examination from April 2004 until the end of 2005 are as follows:

$\begin{array}{llcccl}\begin{array}{c}\text { Section } \\ \mathbf{2 0 0 4}\end{array} & \begin{array}{c}\text { Jan/Feb } \\ \mathbf{2 0 0 4}\end{array} & \begin{array}{c}\text { April/May } \\ \mathbf{2 0 0 4}\end{array} & \begin{array}{c}\text { July/Aug } \\ \mathbf{2 0 0 4}\end{array} & \begin{array}{c}\text { Oct/Nov } \\ \mathbf{2 0 0 4}\end{array} & \underline{\underline{\text { Cumulative }}} \\ \text { AUDIT } & \text { N/A } & 48.42 \% & 42.99 \% & 38.53 \% & 42.54 \% \\ \text { BEC } & \text { N/A } & 44.12 \% & 44.66 \% & 44.76 \% & 44.61 \% \\ \text { FAR } & \text { N/A } & 46.60 \% & 43.74 \% & 38.10 \% & 42.09 \% \\ \text { REG } & \text { N/A } & 47.47 \% & 42.32 \% & 35.06 \% & 40.67 \% \\ & & & & & \\ \text { Section } & \text { Jan/Feb } & \text { April/May } & \text { July/Aug } & \text { Oct/Nov } & \\ \underline{\mathbf{2 0 0 5}} & \underline{\mathbf{2 0 0 5}} & \underline{\mathbf{2 0 0 5}} & \underline{\mathbf{2 0 0 5}} & \underline{\mathbf{2 0 0 5}} & \underline{\text { Cumulative }} \\ \text { AUDIT } & 39.62 \% & 46.15 \% & 44.92 \% & 42.94 \% & 43.62 \% \\ \text { BEC } & 43.19 \% & 42.70 \% & 48.57 \% & 41.82 \% & 44.16 \% \\ \text { FAR } & 36.44 \% & 43.68 \% & 48.05 \% & 42.17 \% & 43.11 \% \\ \text { REG } & 35.34 & 42.26 \% & 43.47 \% & 39.93 \% & 40.61 \%\end{array}$

At the other end of the scale are those certifications that are, at best, a fraud. Some are like the "mailorder" $\mathrm{PhD}$. Fill out a short form asking for personal information and mail it and a check or money order to ... the emphasis here would be on "check or money order." In most instances employers recognize this type of certification for what it is, a sham, and treat its holder with the "respect" the certificate has earned.

Between the two extremes lie many legitimate certifications that lend prestige and value to the holder. The western trained accountant should recognize that top intellectual capital is available to local entrepreneurs wherever he or she may be. Gone are the days of the western trained accountants' domination of the profession. We should expect intense competition from local talent. The serious accountant, if $\mathrm{h} / \mathrm{she}$ expects to be able to compete, must build his portfolio of qualifications. S/he should investigate and choose those certifications that lend value to the portfolio for the geographical region in which s/he wishes to work. The ultimate result should be a list of certificates reflecting his/her knowledge and expertise in the field(s) in which s/he practices and in the countries in which s/he works. A discussion on international accounting standards and the shift to different standards which emphasizes the global nature of this industry shows that it is a new era for the accountant and aspirants should begin planning for the certification with knowledge about the process that will prevent lost time and miss-directed study.

\section{AUTHOR INFORMATION}

Dr. Priscilla Berry, currently an Assistant Professor of Communications in the Davis College of Business at Jacksonville University, has a private communications consulting practice: Berry and Associates, which provides businesses with specialized programs to assist with cultural transformation and leadership development, solving internal and public communication challenges. Dr. Berry is a graduate of the University of Mississippi with degrees in English, Literature, and Humanities. She began her career in academia as a professor of literature and writing, but was recruited by local corporations to work on the development and facilitation of communication systems. Selected Corporate Clients include: Communications Planning Corp, Children's Haven, Americall, LDC, DuPont, Interline (U.S. West), Duval County School Board, CSX, the Jacksonville Symphony, and the Army Corp of Engineers. She was a guest professor for a semester at the University of Caen in France where she lectured to international postgraduates on Doing Business in a Global Economy.

Dr. David T. Boyd, CPA, CMA, CFE, CFM, CrFA is in his fourth decade of practicing and teaching accounting and finance nationally and internationally. He has published in numerous national and international journals and presented many refereed papers at conferences around the world. He considers the classroom his second home and is currently a professor of accounting in Almaty Kazakhstan at the Kazakhstan Institute of Management, Economics and Strategic Research. 
Dr. Sanithia C. Boyd, CPA, CMA, CFE, CrFA has been teaching and practicing accounting for more than 30 years. She has traveled the globe teaching in the classroom, consulting with companies wherever she happens to be, publishing in journals, and presenting papers at a variety of national and internalional conferences. She is currently a professor of accounting at the Kazakhstan Institute of Management, Economics and Strategic Research in Almaty Kazakhstan.

\section{REFERENCES}

1. American Institute of Certified Public Accountants. (2009). CPA Exam Requirements. Retrieved June 2009 from http://www.nasba.org/nasbaweb.nsf/exam

2. Biersktaker, J., Howe, M. \& Seol, I. (Nov/Dec, 2005. The Effects of the 150-Credit Hour Requirements for the Certified Public Accountant Exam on the Career Intentions of Women and Minorities. Journal of Education for Business, 81(2), 99-105.

3. Bradford, T. (April 28, 2007). CPA and CMA Education Requirements: Education Required to be a Certified Public or Management Accountant Retrieved May 2009 from http://www. Accountingdesignations. suite101.com/article.cfm

4. $\quad$ CPA Exam Application Process. (2009). Retrieved June 2009 from http://www.Bus.lsu.edu/academics/accounting/Courses_Info/CPA Requirements

5. Gleim Accounting (2008). CPA Requirements and Regulations Instructions by State. Retrieved April 10, 2008 from http://www.gleim.com/accounting/cpa/requirements.

6. Johnson, G. (February/March 2004). The Uniform CPA Examination Alert. Retrieved May 2009 from http://www.cpa-exam.org.

7. Seda, M., Kramer, B. \& Peterson, K. (spring, 2008). The Emergence of Forensic Accounting Programs in Higher Education. Management Quarterly, 9(3), 15-24.

8. Wood, H. (2008). CPA Eligibility Requirements. Retrieved June 2008 from http://www.ehow.com/about cpa-eligibility-requirements.html. 


\section{APPENDIX}

\begin{tabular}{|c|c|c|c|}
\hline State & Web Address & State & Web Address \\
\hline Alabama & www.asbpa.alabama.gov & Montana & www.publicaccountant.mt.gov \\
\hline Alaska & www.commerce.state.ak.us/occ/pcpa.htm & Nebraska & www.nol.org/home/BPA \\
\hline Arizona & www.azaccountancy.gov & Nevada & www.nvaccountancy.com \\
\hline Arkansas & www.state.ar.us/asbpa & $\begin{array}{l}\text { New } \\
\text { Hampshire }\end{array}$ & www.nh.gov \\
\hline California & www.dca.ca.gov/cba & New Jersey & www.state.nj.us/lps/ca/nonmed.htm \\
\hline Colorado & www.dora.state.co.us/accountants & $\begin{array}{l}\text { New } \\
\text { Mexico }\end{array}$ & $\begin{array}{l}\text { www.rld.state.nm.us/b\&c/accountanc } \\
\text { y/index.htm }\end{array}$ \\
\hline Connecticut & www.ct.gov/sboa & New York & www.op.nysed.gov/cpa.htm \\
\hline Delaware & www.dpr.delaware.gov & $\begin{array}{l}\text { North } \\
\text { Carolina }\end{array}$ & www.nccpaboard.gov \\
\hline Florida & www.myflorida.com & $\begin{array}{l}\text { North } \\
\text { Dakota }\end{array}$ & $\underline{\text { www.state.nd.us/ndsba }}$ \\
\hline Georgia & www.sos.state.ga.us/plb/accountancy & Ohio & www.acc.ohio.gov \\
\hline Hawaii & www.hawaii.gov/dcca/areas/pvl/boards/accountancy & Oklahoma & www.oab.state.ok.us \\
\hline Idaho & www.isba.idaho.gov & Oregon & Egov.oregon.gov/BOA \\
\hline Illinois & www.ilboa.org & $\begin{array}{l}\text { Pennsylvani } \\
\text { a }\end{array}$ & www.dos.state.pa.us/account \\
\hline Indiana & www.in.gov/pla/bandc/accountancy & $\begin{array}{l}\text { Rhode } \\
\text { Island }\end{array}$ & www.dbr.state.ri.us \\
\hline Iowa & www.state.ia.us/iacc & $\begin{array}{l}\text { South } \\
\text { Carolina }\end{array}$ & $\begin{array}{l}\text { www.llr.state.sc.us/POL/Accountanc } \\
\underline{y}\end{array}$ \\
\hline Kansas & www.ksboa.org & $\begin{array}{l}\text { South } \\
\text { Dakota }\end{array}$ & $\underline{\text { www.state.sd.us/dcr/accountancy }}$ \\
\hline Kentucky & Cpa.ky.gov & Tennessee & $\begin{array}{l}\text { www.state.tn.us/commerce/boards/tn } \\
\text { sba/index.html }\end{array}$ \\
\hline Louisiana & www.cpaboard.state.la.us & Texas & www.tsbpa.state.tx.us \\
\hline Maine & www.maineprofessionalreg.org & Utah & www.dopl.utah.gov \\
\hline Maryland & www.dllr.state.md.us/license/occprof/account.html & Vermont & $\begin{array}{l}\text { www.vtprofessionals.org/opr1/accou } \\
\text { ntants }\end{array}$ \\
\hline $\begin{array}{l}\text { Massachuset } \\
\text { ts }\end{array}$ & www.mass.gov/reg/boards/pa & Virginia & www.boa.virginia.gov \\
\hline Michigan & www.michigan.gov/accountancy & Washington & www.cpaboard.wa.gov \\
\hline Minnesota & $\underline{\text { www.boa.state.mn.us }}$ & $\begin{array}{l}\text { West } \\
\text { Virginia }\end{array}$ & www.wvboacc.org \\
\hline Mississippi & www.msbpa.state.ms.us & Wisconsin & drl.wi.gov/index.htm \\
\hline \multirow[t]{2}{*}{ Missouri } & pr.mo.gov/accountancy.asp & Wyoming & cpaboard.state.wy.us \\
\hline & Others & & \\
\hline $\begin{array}{l}\text { District } \\
\text { of Columbia }\end{array}$ & $\frac{\text { dcra.dc.gov/dcra/cwp/view,a,1342,q,600568,dcraNav }}{\text { GID,1696,dcraNav,|33448|.asp }}$ & & \\
\hline Guam & www.guamboa.org & & \\
\hline Puerto Rico & www.estado.gobiemo.pr/contador.htm & & \\
\hline $\begin{array}{l}\text { Virgin } \\
\text { Islands }\end{array}$ & www.dlca.gov.vi & & \\
\hline
\end{tabular}


Table II

Non-American Accounting Certifications

\begin{tabular}{|l|l|}
\hline \multicolumn{1}{|c|}{ Certification/Country } & \multicolumn{1}{c|}{ Certification/Country } \\
\hline $\begin{array}{l}\text { Certified General Accountant } \\
\text { Canada }\end{array}$ & Certified Management Accountant \\
Canada \\
\hline $\begin{array}{l}\text { Certified Practicing Accountant } \\
\text { Australia }\end{array}$ & Chartered Accountant \\
& Australia Nepal \\
& Bahamas New Zealand \\
& Bangladesh Nigeria \\
Certified Public Accountant & Barbados Pakistan \\
Japan & Canada Scotland Song Kong Sierra Leone \\
People's Republic of China & Ghana Sri Lanka \\
Taiwan & Guyana South Africa \\
& India Trinidad and Tobago \\
& Ireland Jamaica United Kingdom \\
& Malaysia Zimbabwe \\
\hline Wirtschaftsprufer & Namibia \\
Germany & Register Accountant \\
\hline
\end{tabular}

\section{NOTES}

